\title{
RADIATION DAMAGE IN URANIUM TARGET OF THE ACCELERATOR DRIVEN SYSTEM "KIPT NEUTRON SOURCE"
}

\author{
V.V. Gann, A.V. Gann, B.V. Borts, I.M. Karnaukhov, A.A. Parkhomenko \\ National Science Center "Kharkov Institute of Physics and Technology", \\ Kharkiv, Ukraine \\ E-mail: gann @kipt.kharkov.ua
}

In this work, the rate of radiation damage production in a uranium target of the neutron source at NSC KIPT under electrons irradiation with an energy of $100 \mathrm{MeV}$ was estimated. The contribution of elastic and inelastic processes is determined: high-energy electrons and gamma quanta, photo-neutron production, fragments arising from photo-fission, damage from neutrons. It was found that the main input into damage production in a uranium target give fragments of photo-fission.

\section{INTRODUCTION}

One of the most important scientific projects carried out in Ukraine is the creation at the NSC KIPT, together with the Argonne National Laboratory in the USA, a research nuclear facility "Neutron source based on a subcritical assembly driving by an electron accelerator" (hereinafter ADS "Neutron source"), as a stage for creation nuclear reactors of the 5th generation [1]. The ADS "Neutron source" was constructed to study the properties of accelerator driven subcritical nuclear systems, use neutrons in applied and fundamental scientific research, as production of medical isotopes, and for training specialists in the field of nuclear energy use.

The process of obtaining a high flux of neutrons in the ADS "Neutron source" is based on the multiplication of primary neutrons in a subcritical assembly made of low-enriched uranium. A high-current accelerator of relativistic electrons (of energy $100 \mathrm{MeV}, 1 \mathrm{~mA}$ ) irradiating a neutron-producing target (NPT) is used to generate external neutrons. High energy gamma quanta arise from bremsstrahlung of an electrons in the target material. They participate in photonuclear reactions on heavy nuclei (W or $\mathrm{U}$ ) and knock out neutrons [2]. In uranium NPT, neutrons are also generated in the photo-fission reactions on $\mathrm{U}-238$ nuclei.

The target consists of a set of $66 \times 66 \mathrm{~mm}$ square plates with gaps of $1.75 \mathrm{~mm}$ water between them Total thickness of the target is $80 \mathrm{~mm}$. This design of the NPT gives the integral neutron yield $3.0 \cdot 10^{14} \mathrm{n} / \mathrm{s}$ at total beam power [1].

Among the priority tasks facing the Project participants is evaluation operation time of the facility individual elements, and, first of all, the resource of the NPT, which is determined by the value of the limiting dose of radiation damage in units of displacements per atom (dpa) for the target material.

In articles [3-6] calculations of the radiation damage dose were carried out for various materials in different ranges of electrons and gamma-quanta energies.

In this paper, the radiation damage dose in a uranium target was estimated for normal operation conditions, that is, under irradiation by electrons with an energy of $100 \mathrm{MeV}$ and by neutrons with integral fluxes of $10^{19} \ldots 10^{20} \mathrm{n} / \mathrm{cm}^{2}$ at relatively low temperatures of the target (no higher than $100^{\circ} \mathrm{C}$ ). Contributions of elastic and inelastic processes: scattering of high-energy electrons and gamma-quanta, production of photo-neutrons, damage from neutrons and from fragments of nuclear photo-fission were taken into account.

\section{METHOD AND CALCULATION THE RADIATION DAMAGE DOSE \\ 1.1. HIGH ENERGY ELECTRONS}

Electrons of $\mathrm{MeV}$ energy range when moving in a target lose their energy to excite and ionize atoms, to emit bremsstrahlung gamma rays and to create radiation damage in the material.

The defect concentration achieved under irradiation by electrons with energy $E$ can be described by the radiation dose $D$, which is characterized by the average number of displacements per atom of the material:

$$
D=\sigma_{\mathrm{D}}(E) \Phi(E) t,
$$

where $\Phi$ is the electron flux, $t$ is the irradiation time. The defect production cross section $\sigma_{D}(E)$ is expressed in the terms of the cross section for electron scattering on nuclei [7]:

$$
\sigma_{D}(E)=\int_{T_{\min }}^{T_{\max }} \frac{d \sigma(E, T)}{d T} v(T) d T .
$$

Here $d \sigma(E, T) / d T$ is the cross section of the transfer of energy $T$ to the nucleus during the scattering of an electron with energy $E, E_{d}$ is threshold energy for atom displacement $\left(E_{d}=38.5 \mathrm{eV}\right.$ for $\left.U\right), v(T)=0.8 T /\left(2 E_{d}\right)$ is the cascade function of NRT-standard [8], $T_{\max }(E)=2 E\left(E+2 m_{e} c^{2}\right) /\left(A m_{p} c^{2}\right)$ is the maximal energy, transferred to the nuclei, $m_{e}$ is the electron mass, $m_{p}-$ is the proton mass.

The differential cross section of elastic scattering of an electron at an angle $\theta$ at the solid angle $d \Omega$ in the second Born approximation is expressed by the following formula [9]:

$$
\begin{aligned}
& \frac{d \sigma}{d \Omega}=|F(q)|^{2} \sigma_{R}\left\{1-\beta^{2} \sin ^{2}(\theta / 2)+\right. \\
& +\pi Z \alpha \beta \sin (\theta / 2)[1-\sin (\theta / 2)]\},
\end{aligned}
$$

where $\sigma_{\mathrm{R}}-$ is the Rutherford elastic cross section of electron scattering on a point nucleus, $F(q)-$ is the form 
factor of the nucleus, $q$ is the momentum transferred to the nucleus, $\beta=v / c, v$ is the electron velocity, $c$ is the speed of light, $\alpha=1 / 137$ is the fine structure constant,

$$
\sigma_{R}=\left(\frac{Z e^{2}}{2 m_{e} c^{2}}\right)^{2} \frac{1-\beta^{2}}{\beta^{2} \sin ^{4}(\theta / 2)} .
$$

Here $Z-$ is the nuclear charge,

$$
\begin{aligned}
& F(q)=\int \rho(r) \exp (i \vec{q} \vec{r} / \hbar) d V ; \\
& \rho(r)=\rho_{0} /\{1+\exp [(r-R) / a]\},
\end{aligned}
$$

where $\rho(r)$ - is the density of nucleons in the nucleus, $R \approx 1.3 A^{1 / 3} \mathrm{Fm}$ is the radius of the nucleus, $A$ is the atomic weight of the nucleus, $a \approx 0.55 \mathrm{Fm}$ is the uncertainty of the nucleus boundary, $\rho_{0} \approx 0.17 \mathrm{n} / \mathrm{Fm}^{3}$.

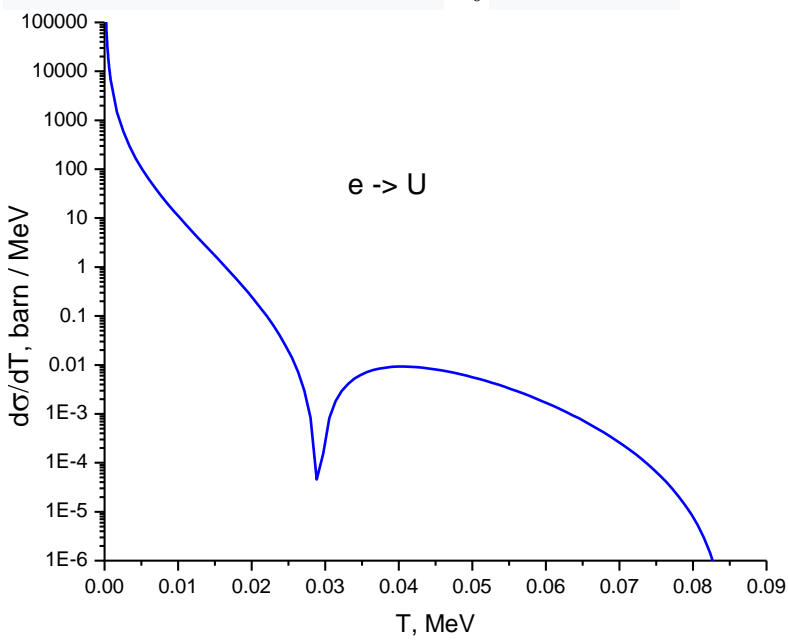

Fig. 1. Cross section for elastic scattering of electrons by the $U-238$ nucleus

To use equation (2), in expression (3) one should pass from the scattering angle $\theta$ to the energy $\mathrm{T}$ transferred to the recoil nucleus [10]:

$$
T=\frac{q^{2}}{2 M}=2 \sin ^{2}(\theta / 2) \frac{\beta^{2}}{\left(1-\beta^{2}\right) M} .
$$

Substituting (6) into (3), we get:

$$
\frac{d \sigma}{d T}=\frac{4 \pi}{T_{\max }} \frac{d \sigma}{d \Omega}
$$

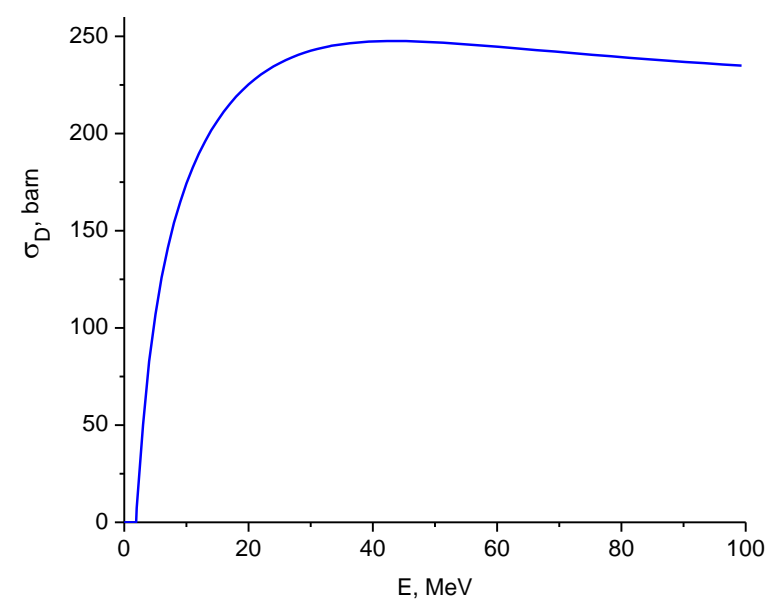

Fig. 2. Dependence of the defect production crosssection on the electron energy $E$ in $U$
The cross section for elastic scattering of electrons with energy $E$ on the U-238 nucleus with energy transfer $T$ is plotted in Fig. 1 [7].

Fig. 2 shows the dependence of the defect production cross section $\sigma_{\mathrm{D}}$ on the electron energy for U-238 [7].

Using the data in Fig. 2 (cross section $\sigma_{\mathrm{D}}=235$ barn), it is possible to calculate the rate of defect production $R=\Phi \sigma_{D}$ near the surface of a uranium target irradiated with electrons of energy of $E=$ $100 \mathrm{MeV}$. Taking into account the electron flux density $\Phi=1.7 \cdot 10^{14} \mathrm{e} /\left(\mathrm{cm}^{2} \cdot \mathrm{s}\right)$ at beam current of $1 \mathrm{~mA}$, we obtain the defect production rate $R=3.9 \cdot 10^{-8} \mathrm{dpa}$.

\subsection{HIGH ENERGY GAMMA-QUANTA}

When moving in a target, high-energy electrons lose their energy in the processes of ionization and emission of bremsstrahlung gamma-quanta. At energies above $7 \mathrm{MeV}$, the energy losses of electrons in uranium are determined by bremsstrahlung process:

$-\frac{d E}{d x} \approx \frac{E}{t_{r}}$, where $t_{r}-$ is the radiation length (for uranium $t_{r} \approx 0.32 \mathrm{~cm}$, we neglect the dependence on $E$ ).

Thus, the dependence of the electron energy on the depth in the target is estimated by the equation: $E_{e}(x)=E_{0} \exp \left(-x / t_{r}\right)$, where $E_{0}-$ is the energy of the incident electrons. The linear radiation power is determined by the formula $d W / d x \approx E_{e /}(x) / t_{r}$ and the spectral distribution of the radiation is described by an approximate expression:

$$
\frac{d^{2} N}{d x d E_{\gamma}} \approx \frac{\theta\left[E_{e}(x)-E_{\gamma}\right]}{E_{\gamma} t_{r}},
$$

where $\theta(x)-$ is the theta function (equal to one for $x>0$ and to zero otherwise).

Since the electron radiates mainly forward, the emitted photons are simply adding, and the spectrum at a depth $\mathbf{x}$ can be estimated by integrating (8) over path length of electron:

$$
\frac{d N(x)}{d E_{\gamma}} \approx \begin{cases}\frac{x}{E_{\gamma} t_{r}} & \text { if } E_{\gamma}<E_{e}(x) \\ \frac{1}{E_{\gamma}} \ln \left(\frac{E_{0}}{E_{\gamma}}\right) & \text { if } E_{\gamma}>E_{e}(x) .\end{cases}
$$

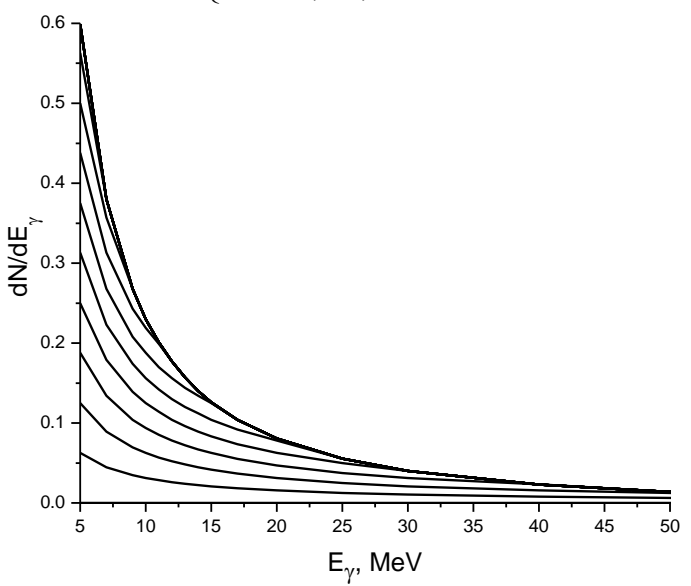

Fig. 3. Spectra of photons in $U$ at different depths 
Fig. 3 shows the spectra of photons in uranium from electrons with an energy of $100 \mathrm{MeV}$ at different depths (curves from bottom to top in order of increasing depth with a step of $0.1 \mathrm{~cm}$ ). Knowing the photon spectra, it is possible for each depth to estimate the values of the photo-neutron yields from the $(\gamma, \mathrm{n})$ and photo-fission reactions, the cross sections of which were taken from [11] and shown in Figs. 4 and 5. The integral cross section for the yield of photo-neutrons in a giant resonance at an energy of $11 \mathrm{MeV}$ is $1.5 \mathrm{barn} \cdot \mathrm{MeV}$, and the integral cross section for photo-fission is $1 \mathrm{barn} \cdot \mathrm{MeV}$ with a maximum at an energy of $14 \mathrm{MeV}$.

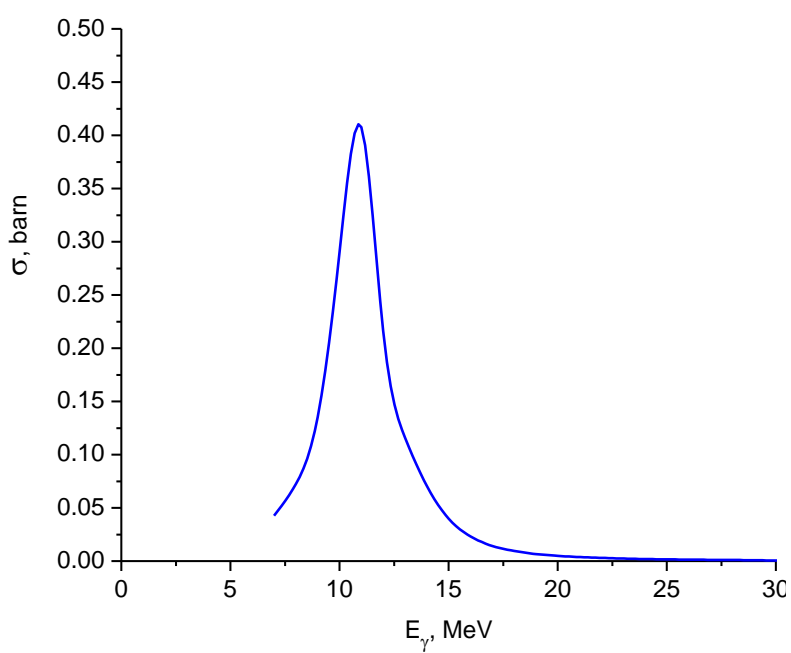

Fig. 4. Dependence of the reaction $(\gamma, n)$ cross section on photon energy for $U-238$

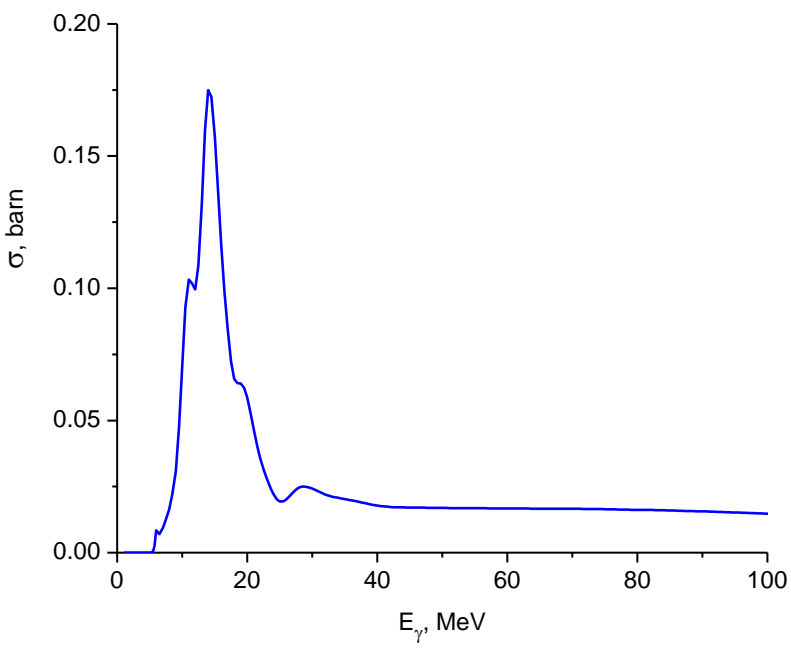

Fig. 5. Dependence of the photo-fission cross section for $U-238$ on photon energy

As a result, we have: the effective cross section for the production of photo-neutrons is $0.32 \mathrm{barn} / \mathrm{e}$, and the effective cross section for photo-fission is 0.14 barn/e. These values are reached at a depth of $0.7 \mathrm{~cm}$.

Emitted photo-neutrons have an energy of about $1 \mathrm{MeV}$, while the recoil nucleus receive an energy of $\sim 4000 \mathrm{eV}$ and creates $\sim 34$ displaced atoms in uranium. Consequently, the cross-section of defect production from this process is 11 barn/e.

Photo-fission produces 2 fragments with a total energy of $\sim 200 \mathrm{MeV}$, which create about 160.000 displaced atoms, which gives an effective cross section of $\sim 22000$ barn/e, the rate of defect formation is $3.7 \cdot 10^{-6} \mathrm{dpa} / \mathrm{s}(0.32 \mathrm{dpa} /$ day $)$. Burnup of U-238 will be $0.7 \cdot 10^{-3}$ per year, which approximately corresponds to this value in thermal reactors of the WWER type.

\subsection{DAMAGE FROM NEUTRONS PRODUCED IN THE TARGET}

When gamma quanta move in a uranium target, neutrons are produced through two channels: the production of photo-neutrons $(\gamma, \mathrm{xn})$ and the production of neutrons due to photo-fission $(\gamma, f)$ with effective cross sections of the order of 0.3 barn/e. Processes of neutron absorption by nuclei $(\mathrm{n}, \gamma)$ take place as well. The neutron flux $\Phi(\mathrm{E}, \mathrm{x})$ can be described by the energy spectrum (Fig. 6) and flux density along the target depth (Fig. 7) [2].

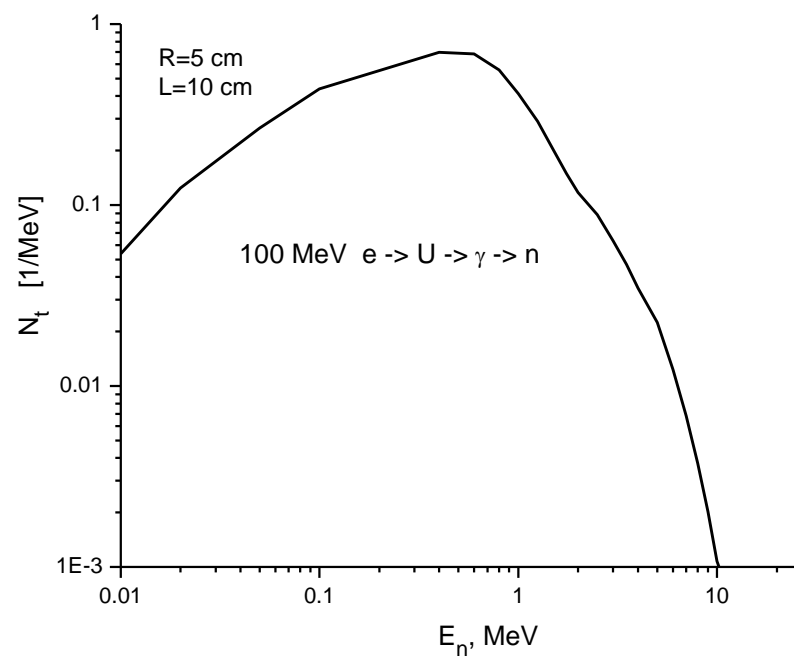

Fig. 6 Normalized spectrum of neutrons produced in the target irradiated with high-energy electrons

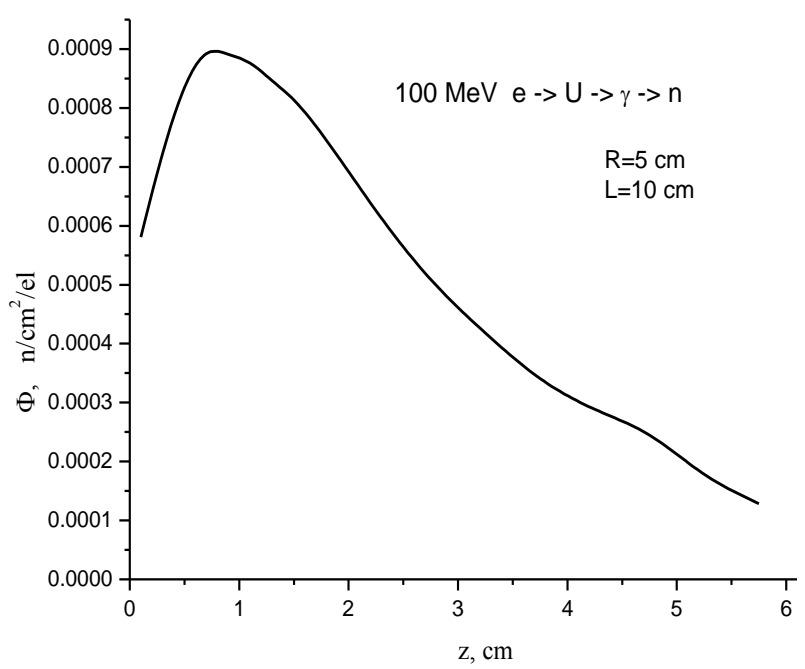

Fig. 7 Neutron flux density over the depth of the target irradiated by electrons with energy of $100 \mathrm{MeV}$

The defect yield rate $R(x)$ is related to the defect production cross section under neutron irradiation $\sigma_{D n}\left(E_{n}\right)$ by the formula:

$$
R(x)=\int \sigma_{D n}\left(E_{n}\right) \Phi_{n}\left(E_{n}, x\right) d E_{n},
$$

where $\sigma_{D n}\left(E_{n}\right)$ for U-238 is plotted in Fig. 8 with blue line (see [12]). $\Phi\left(E_{n}, x\right)=N_{t}\left(E_{n}\right) \varphi(x)-$ is spectral densi- 
ty of neutron flux, $N_{t}\left(E_{n}\right)$ is the normalized neutron spectrum (see Fig. 6); $\varphi(\mathrm{x})$ - is neutron flux density at a depth $x$ (see Fig. 7). According to (10), the rate of displacement production from neutrons generated by the target is about $R=7 \cdot 10^{-8} \mathrm{dpa} / \mathrm{s}$.

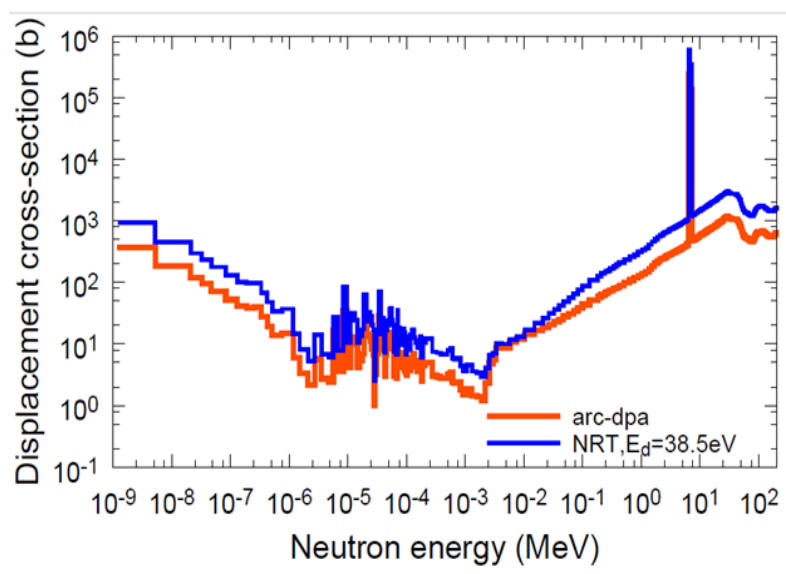

Fig. 8. Energy dependence of defect production cross sections in uranium under neutron irradiation

\subsection{NEUTRONS FROM SUBCRITICAL ASSEMBLY}

The spectrum of neutrons $\Phi_{n}\left(E_{n}\right)$ - near the target surface from the SCA is shown in Fig. 9 [2].

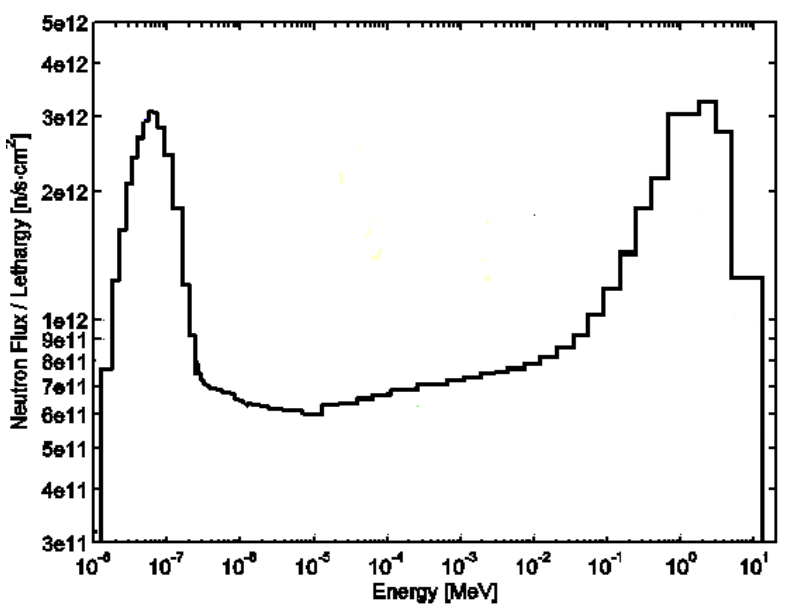

Fig. 9. The spectrum of neutrons $\Phi_{n}\left(E_{n}\right)$ - near the surface of the target from the SCA

Using formula (10), we obtain for the defect formation rate $R$ about $10^{-8} \mathrm{dpa} / \mathrm{s}$.

\section{CONCLUSION}

The general picture of the radiation damage production in uranium target is presented in Table.

The greatest contribution to the rate of damage production in the uranium target of the neutron source under irradiation with electrons with an energy of $100 \mathrm{MeV}$ gives photo-fission fragments. Damage production rate is $3.7 \cdot 10^{-6} \mathrm{dpa} / \mathrm{s}$, whereas contribution of the rest processes (electrons, photo-neutrons, target neutrons, neutrons from fuel assembly) amounts a few percent of this value.

The defect formation cross section for elastic electron scattering is consistent with the results of [10]. The large value 1000 of the DPA cross sections ratio for photo-fission to photo-neutron processes is consistent with the results of the article [4].

\begin{tabular}{|c|c|c|c|c|c|}
\hline & $\begin{array}{c}\text { Electrons } \\
100 \mathrm{MeV}\end{array}$ & $\begin{array}{c}\text { Photo- } \\
\text { neu- } \\
\text { trons }\end{array}$ & $\begin{array}{c}\text { Photo- } \\
\text { fission }\end{array}$ & $\begin{array}{c}\text { Target } \\
\text { neutrons }\end{array}$ & $\begin{array}{c}\text { Assembly } \\
\text { neutrons }\end{array}$ \\
\hline $\begin{array}{c}\text { Recoil } \\
\text { energy }\end{array}$ & Spectrum & $4 \mathrm{keV}$ & $\begin{array}{c}200 \\
\mathrm{MeV}\end{array}$ & $17 \mathrm{keV}$ & $17 \mathrm{keV}$ \\
\hline $\begin{array}{c}\text { DPA } \\
\text { cross } \\
\text { sections }\end{array}$ & 235 barn & $\begin{array}{c}11 \\
\text { barn/e }\end{array}$ & $\begin{array}{c}22000 \\
\text { barn/e }\end{array}$ & $\begin{array}{c}400 \\
\text { barn }\end{array}$ & $\begin{array}{c}400 \\
\text { barn }\end{array}$ \\
\hline $\begin{array}{c}\text { Damage } \\
\text { rate, } \\
\text { dpa/s }\end{array}$ & $4 \cdot 10^{-8}$ & $2 \cdot 10^{-9}$ & $3.7 \cdot 10^{-6}$ & $7 \cdot 10^{-8}$ & $10^{-8}$ \\
\hline $\begin{array}{c}\text { Damage } \\
\text { rate, } \\
\text { dpa/day }\end{array}$ & $3 \cdot 10^{-3}$ & $1.5 \cdot 10^{-4}$ & 0.3 & $6 \cdot 10^{-3}$ & $10^{-3}$ \\
\hline
\end{tabular}

The results presented in the Table are based on wellknown approaches, however, they are only estimates. Exact values can be obtained only using computer simulation of the ADS system.

Acknowledgements. The authors are grateful to Marchenko Yu.A. for help in preparing the publication.

\section{REFERENCES}

1. И.М. Карнаухов, И. Большинский, Б.В. Борц, Й. Гохар и др. Источник нейтронов ННЦ ХФТИ // ВАНТ. Серия «ФРП и РМ». 2012, №3(79), с. 3-17.

2. Y. Gohar, I. Bolshinsky, H. Belch, F. Dunn, R. Kellogg, T. Sofu, A. Talamo, Z. Zhong. Design and analyses of the KIPT source facility concept // National Science Center "Kharkov Institute of Physics and Technology", Kharkiv, Ukraine, July 8-9, 2008.

3. В.Ф. Зеленский, В.А. Стратиенко, В.Н. Мушников, Н.Л. Емец. Экспрессная имитация реакторных повреждений материалов при помощи пучков гаммаквантов // Реакторное материаловедение. М.: «ЦНИИатоминформ», 1978, т. 1, с.154-193.

4. Н.Л. Емец, В.Ф. Зеленский, В.А. Кузьменко, Э.А. Резниченко, Ю.Н. Ранюк, Б.А. Шиляев, В.А. Ямницкий. Радиационное повреждение урана при облучении электронами с энергией до 20 МэВ // ВАНT. Серия «ФРП и РМ». 1980, №3(14), с. 11-16.

5. В.В. Ганн, Н.Л. Емец, В.А. Кузьменко, Ю.Н. Ранюк, Р.П. Слабоспицкий, .А. Шиляев, О.В. Юдин, В.А. Ямницкий. Расчет профилей пространственного распределения дефектов и продуктов ядерных реакций при облучении материалов высокоэнергетическими электронами и гамма-квантами // ВАНТ. Серия «ФРП и РМ». 1981, №2(16), с. 41-46.

6. В.В. Ганн, Л.С. Ожигов, В.А. Ямницкий, Б. Синх, Т. Лефферс, И. Бильде-Соренсон. Порообразование в чистом алюминии, облученном пучком высокоэнергетических электронов и гамма-квантов // ВАНТ. Серия «ФРП и РМ». 1983, №1(24), с. 41-46.

7. В.В. Ганн, О.В. Юдин. Дефектообразование в высокотемпературных сверхпроводниках при электронном облучении // ВАНТ. Серия «ФРП и РМ». 1989, №1(48), c. 63-66.

8. M.J. Norgett, M.T. Robinson, I.M. Torrens. A proposed method of calculating displacement dose rates // Nucl. Engr. and Design. 1975, N 33(1), p. 50. 
9. W.A. Mc Kinly, H. Feschbach. The Coulomb scattering of relativistic electrons by nuclei // Phys. Rev. 1947, v. 74, p. 1759-1763.

10. В.Ф. Зеленский, В.А. Стратиенко, В.К. Хоренко, Л.Д. Ярошевский. Дефектообразование в никеле под действием релятивистских электронов // ВАНT. Серия «ФРП и РМ». 1978, №1(3), с. 22-25.
11. https://www.oecdnea.org/janisweb/book/gammas/U238/

12. https://www.oecdnea.org/dbdata/jeff/jeff33/index.html

Статья поступила в редакциию 12.03.2021 2.

\section{ДЕФЕКТООБРАЗОВАНИЕ В НЕЙТРОНООБРАЗУЮЩЕЙ УРАНОВОЙ МИШЕНИ ИСТОЧНИКА НЕЙТРОНОВ}

\section{В.В. Ганн, А.В Ганн, Б.В. Борц, І.М. Карнаухов, А.А. Пархоменко}

Проведен расчет скорости образования смещений в урановой мишени источника нейтронов ННЦ ХФТИ под действием облучения высокоэнергетическими электронами с энергией 100 МэВ. Рассмотрены вклады упругих и неупругих процессов: рассеяния высокоэнергетических электронов и гамма-квантов, рождения фотонейтронов, осколков фотоделения, повреждений от нейтронов. Установлено, что наибольший вклад в скорость образования повреждений в урановой мишени вносят осколки фотоделения.

\section{УТВОРЕННЯ ПОШКОДЖЕНЬ У НЕЙТРОНОУТВОРЮЮЧИЙ УРАНОВІЙ МІШЕНІ ДЖЕРЕЛА НЕЙТРОНІВ}

\section{В.В. Ганн, Г.В Ганн, Б.В. Борц, І.М. Карнаухов, О.О. Пархоменко}

Проведено розрахунки швидкості утворення зміщень в урановій мішені джерела нейтронів ННЦ ХФТІ під впливом опромінення високоенергетичними електронами з енергією $100 \mathrm{MeB.} \mathrm{Визначено} \mathrm{внесок} \mathrm{пруж-}$ них та непружних процесів: високоенергетичних електронів та гамма-квантів, фотонейтронів, осколків фотоподілу, пошкоджень від нейтронів. Установлено, що найбільшій внесок у швидкість утворення зміщень в урановій мішені створюють осколки фотоподілу. 